\title{
Magnetic nanoparticles in primary neural cell cultures are mainly taken up by microglia
}

\author{
Josephine Pinkernelle ${ }^{1 *}$, Pilar Calatayud ${ }^{2}$, Gerado F Goya ${ }^{2,3}$, Hisham Fansa $^{4}$ and Gerburg Keilhoff ${ }^{1}$
}

\begin{abstract}
Background: Magnetic nanoparticles (MNPs) offer a large range of applications in life sciences. Applications in neurosciences are one focus of interest. Unfortunately, not all groups have access to nanoparticles or the possibility to develop and produce them for their applications. Hence, they have to focus on commercially available particles. Little is known about the uptake of nanoparticles in primary cells. Previously studies mostly reported cellular uptake in cell lines. Here we present a systematic study on the uptake of magnetic nanoparticles (MNPs) by primary cells of the nervous system.

Results: We assessed the internalization in different cell types with confocal and electron microscopy. The analysis confirmed the uptake of MNPs in the cells, probably with endocytotic mechanisms. Furthermore, we compared the uptake in PC12 cells, a rat pheochromocytoma cell line, which is often used as a neuronal cell model, with primary neuronal cells. It was found that the percentage of PC12 cells loaded with MNPs was significantly higher than for neurons. Uptake studies in primary mixed neuronal/glial cultures revealed predominant uptake of MNPs by microglia and an increase in their number. The number of astroglia and oligodendroglia which incorporated MNPs was lower and stable. Primary mixed Schwann cell/fibroblast cultures showed similar MNP uptake of both cell types, but the Schwann cell number decreased after MNP incubation. Organotypic co-cultures of spinal cord slices and peripheral nerve grafts resembled the results of the dispersed primary cell cultures.

Conclusions: The commercial MNPs used activated microglial phagocytosis in both disperse and organotypic culture systems. It can be assumed that in vivo application would induce immune system reactivity, too. Because of this, their usefulness for in vivo neuroscientific implementations can be questioned. Future studies will need to overcome this issue with the use of cell-specific targeting strategies. Additionally, we found that PC12 cells took up significantly more MNPs than primary neurons. This difference indicates that PC12 cells are not a suitable model for natural neuronal uptake of nanoparticles and qualify previous results in PC12 cells.
\end{abstract}

Keywords: Magnetic nanoparticles, Primary neuronal cells, Microglia, Organotypic spinal cord

\section{Background}

Nanoparticles have recently received increased attention in the life sciences. Because of their small size, their cellular uptake mechanisms such as endocytosis [1,2] and the possibility to functionalize them with biofunctional active groups, nanoparticles offer a large range of applications [3-5]. They can be tagged with cell-specific target sites $[6,7]$ and if they are magnetic, they can be moved and influenced by an external magnetic field [8]. One example of these features is cellular hyperthermia of

\footnotetext{
* Correspondence: josephine.pinkernelle@med.ovgu.de

'Institute of Biochemistry and Cell Biology, Otto-von-Guericke University

Magdeburg, Leipziger Str. 44, 39120 Magdeburg, Germany

Full list of author information is available at the end of the article
}

tumours, a novel clinical protocol in which the MNPs are heated up by an alternating magnetic field and tumour cells are destroyed by thermal energy [9].

Another interesting application of magnetic nanoparticles is magnetofection ${ }^{\mathrm{TM}}$. This technique uses them as a carrier for nucleic acids and enhances cell transfection with an external magnetic field [10]. MNPs are already routinely used for contrast enhancement in magnetic resonance imaging, drug delivery, magnetic cell separation, and tissue repair studies [3,11].

One idea for an application in neuroscience is the use of MNPs to promote regeneration within the peripheral (PNS) and central nervous system (CNS). The outcome after injury repair in the nervous system is often poor,

\section{Biomed Central}


even in the PNS $[12,13]$. Here, different cell types participate in the regeneration of the injured nerve. After a peripheral nerve lesion, the axon distal from the injury site degenerates and Schwann cells and later macrophages clean the neural tubes of cell debris and myelin, the socalled Wallerian degeneration. Additionally, Schwann cells produce growth factors and form bands of Büngner as guiding paths for the regrowing axons, building a regeneration-promoting environment [14].

In the CNS, regeneration of injured axons is even more difficult. Unlike Schwann cells, oligodendroglia do not show phagocytic activity. Therefore, an inhibitory environment for axonal regeneration is evident and the clearance of the injury site of cell and myelin debris is much slower than in the PNS. Additionally, the regenerationpromoting environment produced by the Schwann cells in the PNS is absent [15].

Nanoparticles now offer the possibility to influence such processes locally. Mittnacht et al. [16] for example delivered RhoA-specific siRNA by nanoparticles into PC12 cells as a neuronal cell model. Thereby, they suppressed the signal transduction pathway for inhibitory proteins, resulting in enhanced neurite outgrowth of the PC12 cells after stimulation with nerve growth factor (NGF). In contrast, Hamasaki et al. [17] used magnetically labelled neural progenitor cells, which were located by an external magnetic field, to promote axon growth in organotypic co-cultures of brain cortex and spinal cord.

Although there is a trend to use self-produced nanoparticles, reproducibility among different studies would be higher if not every study was based on distinct particles. Thus, we used commercially available MNPs and analyzed their uptake in cells of the nervous system. Unfortunately, there is little literature concerning primary cell cultures and nanoparticles, especially with a neuroscientific background. Mostly, previous studies used different kinds of cell lines such as PC12 as a neuronal model $[16,18]$, human umbilical vein endothelial cells (HUVECs) [19] and Infinity ${ }^{\mathrm{TM}}$ telomerase-immortalised primary human fibroblasts (hTERT-BJ1) [4,20]. However, cell lines are often tumour cells or immortalised cells, behaving differently than primary cells $[21,22]$.

For this reason, we compared neuronal differentiated PC12 cells with primary neuronal cells according to their uptake of green fluorescent MNPs. Primary neuronal cells were used from rat mixed neuronal/glial cerebellar cell cultures. These neuronal cells are mainly granular neurons cultured in a more in vivo like environment having cell contacts with different kinds of glial cells occurring in the cerebellum. Thus, we analyzed the uptake of MNPs for the different kinds of glial cells, too. Together with the analysis of rat primary cell cultures of the PNS, mixed Schwann cell/fibroblast cultures, both culture systems give a good idea which cells will take up nanoparticles in vivo for a future therapeutic approach.

To verify our results in the dispersed cell cultures, organotypic co-cultures of spinal cord slices and peripheral nerve grafts as a more complex model were additionally analyzed. The organotypic co-cultures mimic the tissue architecture of both parts of the nervous system and allow screening of the cellular uptake of MNPs in a more tissue-like environment.

\section{Methods}

\section{Magnetic nanoparticles}

Commercial green fluorescent MNPs produced by Chemicell (4415 nano-screenMAG-ARA, Berlin, Germany) were used. These MNPs have a magnetite core covered by a lipophilic green fluorescent dye and a polysaccharide matrix of glucuronic acid, a derivate of glucose, for additional functionalization. Because of the carboxyl group of the coating polymer, the particles become anionic in solution. Zeta potential measurements of these MNPs suspended in cell culture media revealed a negative charge on the particles; this finding was also observed in the presence of serum supplement. MNPs were diluted the day before use with three different serum-supplemented media: For primary cell cultures MNPs were diluted in Dulbecco's modified Eagle medium (DMEM) medium with $10 \%$ fetal calf serum (FCS), $6 \mathrm{~g} / \mathrm{l} \mathrm{D}$-glucose and 1\% penicillin/streptomycin (pen/strep), resulting in a hydrodynamic MNP diameter of $190 \mathrm{~nm}( \pm 2 \mathrm{~nm})$ and a zeta potential of $-6.1 \mathrm{mV}$. PC12 cells were cultured with MNPs diluted in Roswell Park Memorial Institute (RPMI) medium with 10\% FCS, $50 \mathrm{ng} / \mathrm{ml} \mathrm{NGF} \mathrm{(Sigma,}$ St. Louis, USA), $2 \mathrm{mM}$ L-glutamine and $1 \%$ pen/strep, yielding a hydrodynamic MNP diameter of $199 \mathrm{~nm}( \pm 1$ $\mathrm{nm}$ ) and a zeta potential of $-40.0 \mathrm{mV}$. For the organotypic co-cultures, MNPs were diluted in 50\% Eagle's minimal essential medium (MEM), 25\% Hank's balanced salt solution (HBSS), 25\% FCS, $33.3 \mathrm{mM}$ D-glucose, 1\% pen/ strep and $100 \mathrm{ng} / \mathrm{ml}$ recombinant rat glia cell linederived neurotrophic factor (GDNF, R\&D systems, Minneapolis, USA) giving a hydrodynamic diameter of $185 \mathrm{~nm}( \pm 1 \mathrm{~nm})$ and a zeta potential of $-12.8 \mathrm{mV}$.

\section{Animal care}

All animal experiments were carried out in accordance with the guidelines of the German Animal Welfare Act. The study was approved by the Animal Care and Use Committees of Saxony-Anhalt. Formal approval to conduct the experiments described was obtained from the animal subjects review board of our institution and can be provided upon request. All efforts were made to minimize the number of animals used and their suffering. 


\section{Cerebellar cultures}

5-8 day neonatal rats were decapitated and the cerebellum was separated. Meninges were removed in serumfree DMEM containing $6 \mathrm{~g} / \mathrm{l} \mathrm{D}$-glucose and 1\% pen/ strep. Subsequently, the cerebelli were mechanically dissociated (18 and 23 gauge needles) in serum-free DMEM and centrifuged at $1500 \mathrm{rpm}$ for $5 \mathrm{~min}$. Cells were resuspended in serum-supplemented DMEM with 10\% FCS, $6 \mathrm{~g} / \mathrm{l} \mathrm{D}$-glucose, 1\% pen/strep, counted and seeded for immunocytochemistry in 12 -well plates with $1 * 10^{6}$ cells per well on poly-D-lysine-coated coverslips (18 or $15 \mathrm{~mm}$ ). For viability assay, cerebellar cells were seeded in poly-D-lysine-coated Petri dishes $(35 \mathrm{~mm})$ with a cell density of $2.5^{*} 10^{5}$ cells per dish.

Cells were incubated at $37^{\circ} \mathrm{C}$ in a humidified $6 \% \mathrm{CO}_{2}$ atmosphere and medium was changed $24 \mathrm{~h}$ after preparation to remove cell debris.

For the uptake quantification based on immunocytochemistry, the medium was replaced with MNP medium (50 $\mathrm{\mu g} / \mathrm{ml}$ MNPs) at different time points depending on cell type and different proliferation patterns of the various cell types. For example, the number of neurons decreases over the first week in cerebellar cultures $[23,24]$ and oligodendroglia differentiate from precursor cells after more than one week [25-27]. Quantification of our mixed cerebellar cultures respective the culture composition revealed that they are composed of $45.5 \%$ ( \pm $16.7 \%)$ astroglia, $32.1 \%( \pm 19.2 \%)$ microglia, $24.3 \%$ ( \pm $14.6 \%)$ neurons and no oligodendroglia on day in vitro (DIV) 5. On DIV 7, they contain 35.2\% ( $\pm 17.3 \%$ ) microglia, $32.5 \%( \pm 17.2 \%)$ astroglia, $13.7 \%( \pm 10.4 \%)$ neurons and $2.1 \%( \pm 3.4 \%)$ oligodendroglia. On DIV 13, they are composed of $48.4 \%( \pm 28.4 \%)$ microglia, 38.3\% ( $\pm 24.8 \%)$ astroglia, $1.5 \%( \pm 2.8 \%)$ neurons and $3.0 \%( \pm 4.1 \%)$ oligodendroglia.

To quantify the uptake of neurons, MNP medium was added on DIV 4. MNP uptake in astroglia and microglia was analyzed on DIV 7 and in oligodendroglia on DIV 13. Simultaneously, MNP-free medium was added to control cells.

For viability assay 10,50 or $100 \mu \mathrm{g} / \mathrm{ml} \mathrm{MNP}$-containing medium was added to the cultures on DIV 6. At the same time, MNP-free medium was added to control cells. Cells were incubated for $24 \mathrm{~h}$, washed with phosphate buffered saline (PBS) and used further for immunocytochemistry or for viability assay.

\section{Schwann cell/fibroblast cultures}

5-7 day old rats were decapitated, the spinal ganglia were taken out and collected in a solution of $2 \mathrm{ml}$ serum-free DMEM (6 g/l D-glucose, 1\% pen/strep), $40 \mu$ l collagenase (0.05\%), $100 \mu \mathrm{l}$ hyaluronidase $(0.1 \%)$ and $2 \mathrm{ml}$ dispase II $(1.25 \mathrm{U} / \mathrm{ml})$. In this enzyme-supplemented medium the isolated spinal ganglia were incubated at $37^{\circ} \mathrm{C}$ in a $6 \%$
$\mathrm{CO}_{2}$ humidified atmosphere for ca. $3.5 \mathrm{~h}$ to dissociate the cells enzymatically. The cells were additionally dissociated mechanically using injection needles (18 and 23 gauge needles) and centrifuged at $1500 \mathrm{rpm}$ for $5 \mathrm{~min}$. Afterwards the cells were resuspended in serum-supplemented medium (DMEM, 10\% FCS, 6 g/l D-glucose, 1\% pen/strep).

For immunocytochemistry, 18 or $15 \mathrm{~mm}$ coverslips in 12 -well plates were coated with laminin $(0.05 \mathrm{mg} / \mathrm{ml})$ before seeding $5 * 10^{4}$ cells per well.

For viability assay cells were seeded on laminin-coated Petri dishes $(35 \mathrm{~mm})$ with a cell density of $2.5^{*} 10^{5}$ cells per dish.

Cells were incubated at $37^{\circ} \mathrm{C}$ in a humidified $6 \% \mathrm{CO}_{2}$ atmosphere and the medium was changed $24 \mathrm{~h}$ after preparation to remove cell debris. Culture composition was quantified and revealed $62.7 \%( \pm 17.0 \%)$ Schwann cells and $37.3 \%$ ( $\pm 17.0 \%)$ fibroblasts on DIV 7. For immunocytochemistry and viability assay, the medium was replaced with MNP medium on DIV 6. MNP medium contained $50 \mu \mathrm{g} / \mathrm{ml}$ MNPs for immunocytochemistry and 10,50 and $100 \mu \mathrm{g} / \mathrm{ml}$ MNPs for the viability assay. MNPfree medium was added to control cells. After $24 \mathrm{~h}$, cells were washed with PBS and used further.

\section{Cell line}

PC12 cells were seeded on poly-D-lysine coated culture flasks and cultured with RPMI medium supplemented with $10 \%$ FCS, 2 mM L-glutamine and pen/strep. After $24 \mathrm{~h}$, cells were differentiated with $50 \mathrm{ng} / \mathrm{ml} \mathrm{NGF}$ for 6 days. Differentiated cells were seeded afterwards in 12 -well plates with $1.25^{*} 10^{5}$ cells per well on poly-Dlysine coated coverslips and kept in differentiation medium for 3 days before the medium was replaced with differentiation medium supplemented with $50 \mu \mathrm{g} / \mathrm{ml}$ MNPs. After $24 \mathrm{~h}$, cells were washed with PBS and fixed for immunocytochemistry.

\section{Organotypic spinal cord co-cultures}

Organotypic spinal cords co-cultured with peripheral nerve grafts were prepared according to Vyas et al. [28] with slight modifications. For the cultures, neonatal rats of postnatal day 3-4 were used. Rats were decapitated, the spinal cords excised and roots and meninges removed in dissection buffer (HBSS, $3.4 \mathrm{mM} \mathrm{NaHCO}_{3}, 10 \mathrm{mM}$ HEPES, $33.3 \mathrm{mM}$ D-glucose, $5.8 \mathrm{mM} \mathrm{MgSO}_{4}, 0.03 \%$ bovine serum albumin (BSA), 1\% pen/strep).

The lumbar part of the spinal cord was cut into $350 \mu \mathrm{m}$ transverse sections with a McIlwain tissue chopper (Mickle Laboratory Engineering, Gomshall, UK). About 10 usable sections could be obtained from one lumbar spinal cord part. Three slices were cultured on one Millicell membrane insert (Millipore, Billerica, USA) placed in 6 -well plates. Each well contained $1 \mathrm{ml}$ of medium 
composed of 50\% MEM, 25\% HBSS, 25\% FCS, $33.3 \mathrm{mM}$ D-glucose, $1 \%$ pen/strep and $100 \mathrm{ng} / \mathrm{ml}$ GDNF to keep the motor neurons in the culture alive.

To enhance the motor neuronal survival and to guide sprouting neurites, a co-culture of the spinal cord slice with a peripheral nerve graft as a reconstructed ventral root was chosen.

As peripheral nerve graft, pieces of ulnar and median nerves were harvested from the same animals and one graft was opposed to the ventral surface of each spinal cord slice.

To check the contribution of MNPs in the tissue slices, $100 \mu \mathrm{g} / \mathrm{ml}$ MNPs were added to the medium for the whole culture time. Co-cultures were incubated at $37^{\circ} \mathrm{C}$ in humidified $6 \% \mathrm{CO}_{2}$ atmosphere. The medium was changed $24 \mathrm{~h}$ after preparation and afterwards every second day.

\section{Immunocytochemistry of cell cultures Staining procedure}

After 24 h MNP incubation, cells were washed once with PBS to remove free-floating MNPs and fixed for $30 \mathrm{~min}$ with 4\% paraformaldehyde (PFA). Fixing was followed by three times washing with PBS. Unspecific binding sides were blocked for $1 \mathrm{~h}$ with $10 \%$ FCS, $0.3 \%$ Triton-X in PBS Subsequently, cells were incubated with the primary antibody overnight at $4^{\circ} \mathrm{C}$. Cell type specific primary antibodies were chosen: primary neurons were stained with mouse monoclonal anti-microtubule associated protein-2 (MAP2, 1:1000, Sternberger Monoclonals, Baltimore, USA), PC12 cells with rabbit polyclonal anti-ß-III-tubulin (1:1000, Covance, Princeton, USA), microglial cells with mouse monoclonal anti-CD11b/c (1:400, BD Pharmigen, Franklin Lakes, USA) or with rabbit polyclonal antiionized calcium binding adaptor molecule 1 (IBA-1, 1:1000, Wako Pure Chemicals Industries, Osaka, Japan), astroglia with rabbit polyclonal anti- glial fibrillary acidic protein (GFAP, 1:500, Progen, Heidelberg, Germany) and oligodendroglia with mouse monoclonal anti-galactocerebroside (1:250, Chemicon, Billerica, USA). Schwann cells were stained with rabbit polyclonal anti-S100 (1:200, DAKO, Glostrup, Denmark) and fibroblasts with mouse monoclonal anti-fibronectin (1:200, Abcam, Cambridge, UK) antibody. Primary antibodies were diluted in PBS containing $0.3 \%$ Triton-X and 1\% FCS.

After incubation overnight, cells were washed three times with PBS and incubated for $3 \mathrm{~h}$ with an anti-rabbit or anti-mouse Alexa Fluor 546 Dye secondary antibody (Invitrogen, Carlsbad, USA) diluted 1:200 in PBS. Cells were washed again three times with PBS and cell nuclei were counterstained with 4', 6-diamidino-2-phenylindole (DAPI, $1 \mu \mathrm{g} / \mathrm{ml}$ diluted in PBS, Roche Applied Science, Indianapolis, USA). After washing again with PBS, coverslips were embedded with Immu-Mount (Thermo Scientific, Waltham, USA).

\section{Quantification}

To quantify the cellular uptake cell type specific antibodies were used to stain cell lines followed by counterstaining all nuclei with DAPI. Control coverslips (4-5) and 10 coverslips of the MNP-incubated cells were used and 4-5 random images per coverslip (each corner and middle) were taken. Images were acquired with an AxioImager microscope (Zeiss, Jena, Germany). Total cell number (given by the DAPI-staining), the number of cell type specific stained cells (for example neurons) and the number of cells which were co-localized with the green fluorescent MNPs were counted with the AxioVision Rel. 4.8 Imaging software by Zeiss. Values were calculated as a percentage to the total cell number providing the percentage specific cell types in the cultures. Total uptake was calculated as percentage of specific cell type with MNP co-localization to the total number of this specific cell type.

In PC12 cells, the total cell number, the number of clearly differentiated cells (cells with $ß$-III-tubulin expression and neurite growth) and the number of differentiated cells co-localized with MNPs was quantified and calculated in a similar manner.

Statistical analysis was performed with Graph Pad Prism 4 (GraphPad Software, La Jolla, USA) using an unpaired t-test for the comparison of control and MNP group. For each cell type $n=20$ images from 4-5 coverslips were chosen. For the comparison of the MNP uptake between the different cell types in the cerebellar cultures a one-way ANOVA followed by a Bonferroni post-hoc test was performed ( $\mathrm{n}=40$ images from 10 coverslips). The comparison of the MNP uptake between primary neurons/PC12 cells and between Schwann cells/fibroblasts was done with an unpaired t-test (both $n=40$ images from 10 coverslips). In all statistical tests a $\mathrm{p}$-value $\leq 0.05$ was considered to be statistically significant.

\section{Immunohistochemistry of organotypic co-culture Staining procedure}

Cultures were fixed after one week by replacing the medium with $4 \%$ PFA overnight. For immunohistochemistry, the membranes of inserts were separated from the carrier and cultures attached on membranes were stained freefloating according to the protocol described above. As primary antibodies mouse monoclonal anti-pan-neuronal neurofilament marker (1:1000, Sternberger Monoclonals), rabbit polyclonal anti-ß-III-tubulin (1:1000, Covance), mouse monoclonal anti-CD11b/c (1:400, BD Pharmigen), rabbit polyclonal anti-GFAP (1:500, Progen), rabbit polyclonal anti-S100 (1:200, DAKO) and rabbit polyclonal anti-myelin basic protein (1:200, Chemicon) were used to visualize the main cell types. 


\section{Imaging}

Organotypic co-cultures were imaged with a TCS SPE DMI4000 confocal microscope by Leica (Wetzlar, Germany) and edited in the Leica Application Suite 2.3. Figure 1 shows a phase contrast image of a spinal cord co-culture. This picture was taken with a cell culture microscope DMI3000 by Leica and was edited with Photoshop CS4 (Adobe Incorporated Systems, San Jose, USA) to create a collage of the whole co-culture. Images of motor neurons were taken at the ventral part of the spinal cord as marked in Figure 1 by the upper white box. Images of other cell types were taken in the vicinity of the intersection of the spinal cord slice and the peripheral nerve graft, marked by the other boxes in Figure 1.

\section{Electron microscopy}

Cultures were fixed for $24 \mathrm{~h}$ with $4 \%$ PFA. They were washed with $0.1 \mathrm{M}$ cacodylate buffer and incubated for $1 \mathrm{~h}$ with $1 \%$ osmium tetroxide, washed again with $0.1 \mathrm{M}$ cacodylate buffer and 50\% ethanol and incubated with $2 \%$ uranyl acetate for $1 \mathrm{~h}$. Subsequently, cells were dehydrated in an ascending ethanol series and embedded in
Durcupan $^{\mathrm{TM}}$ ACM Fluka (Sigma, St. Louis, USA). After hardening at $68^{\circ} \mathrm{C}$, cell culture plastic was removed and cells were cut in ultra-thin slices of $70 \mathrm{~nm}$. Images were taken with an EM 900 transmission electronic microscope by Zeiss and edited with Adobe Photoshop CS4.

\section{Viability assay of cell cultures}

To reveal changes in cell viability of primary cell cultures incubated with MNPs, an MTS (3-(4.5-dimethylthiazol-2yl)-5-(3-carboxymethoxyphenyl)-2-(4-sulfophenyl)-2H-tetrazolium) proliferation assay (CellTiter 96 Aqueous one solution cell proliferation assay by Promega, Madison, USA) was used. To avoid previously reported and discussed interferences of nanoparticles with colorimetric assays and absorbance measurement [29], the experimental protocol of the MTS assay was slightly changed. Cells of both primary cell cultures were incubated on DIV 6 for $24 \mathrm{~h}$ with MNP medium containing different concentrations of MNPs $(10,50$ and $100 \mu \mathrm{g} / \mathrm{ml}$, each with $\mathrm{n}=10$ for Schwann cell/fibroblast cultures and $n=12$ for cerebellar cultures). Control cells received MNP-free medium. After $24 \mathrm{~h}$ of incubation, the medium was removed and cells were washed once with sterile PBS. New MNP-free

\section{spinal cord slice}

peripheral nerve graft

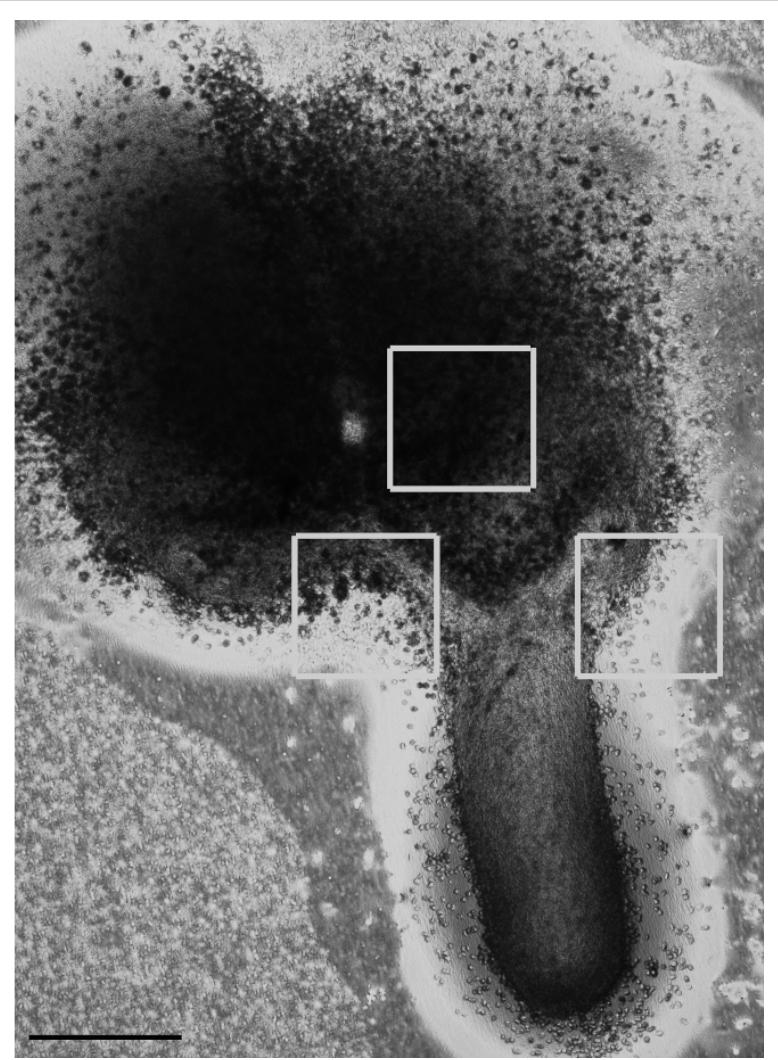

Figure 1 Phase contrast of an organotypic co-culture of spinal cord and peripheral nerve graft. Boxes indicate imaged regions for confocal microscopic analysis of different cell types including neurons, microglia, astroglia, oligodendroglia and Schwann cells. Bar represents $500 \mu \mathrm{m}$. 
medium and MTS reagent were added. Cells were incubated for $3 \mathrm{~h}$ at $37^{\circ} \mathrm{C}$ in humidified $6 \% \mathrm{CO}_{2}$ atmosphere. All values were normalized by the mean of the blank.

After incubation the absorbance was measured with a Tecan M200 microplate reader (Tecan, Männedorf, Switzerland) at $490 \mathrm{~nm}$. Two values per Petri dish were determined and the mean used for statistical analysis. Statistical analysis was performed with GraphPad Prism 4 using a one-way ANOVA followed by Dunnett's post-hoc test. A p-value $\leq 0.05$ was considered to be statistically significant.

To check for integrity of the cell cultures, staining of cells with nuclear fast red-aluminium sulphate and Prussian blue was performed. Prussian blue stained iron-(III) oxide and visualized remaining MNPs (Figure 2). Images for each group were acquired with an AxioImager microscope (Zeiss).

\section{Results}

\section{Cellular uptake}

In this study we used anionic MNPs for uptake analysis in cells of the nervous system. Previous studies reported that the uptake of anionic nanoparticles in cells is mainly mediated by endocytosis [30]. Because of this, we initially looked at the localization of MNPs using nuclear fast red-aluminium sulphate and Prussian blue staining in mixed cerebellar and Schwann cell/fibroblast cultures (Figure 2). Cultures of the control (Figure 2A, C) and the
MNP group (Figure 2B, D) revealed no visual differences in culture integrity and composition. MNPs showed mainly cellular localization in the cerebellar cultures (Figure 2B, arrows) and in Schwann cell/fibroblast cultures (Figure 2D, arrows). To look in more detail, we used confocal and electron microscopy. Confocal microscopy demonstrated green fluorescent MNPs inside the cells and 3-D projections illustrated that MNPs were coplanar with the cell bodies and nucleus (Figure 3). The amount of MNPs inside cells fluctuated between the cell types; e.g. microglia (Figure 3A) displayed a high amount of MNPs whereas PC12 cells (Figure 3B) and Schwann cells (Figure 3C) took them up to a lesser extent. Electron microscopy revealed an accumulation of MNPs in intracellular vesicular compartments in microglial cells (Figure 4A, arrows) and Schwann cells (Figure 4B, arrow), confirming an endocytotic uptake mechanism.

\section{Cell cultures}

Mixed cerebellar cultures were incubated for $24 \mathrm{~h}$ with MNPs on DIV 4. At this time point, mixed cerebellar cultures contained $17.7 \%( \pm 1.7 \% \mathrm{SD})$ detected neurons in the control cultures and $16.5 \%( \pm 2.2 \% \mathrm{SD})$ detected neurons in the cultures incubated with MNPs.

Cultures of PC12 cells revealed $57.5 \%( \pm 4.4 \%$ SD) clearly differentiated cells in the control and $53.4 \%( \pm$ $3.5 \% \mathrm{SD})$ differentiated cells in the cultures incubated with the MNPs. Overall, incubation of primary neurons
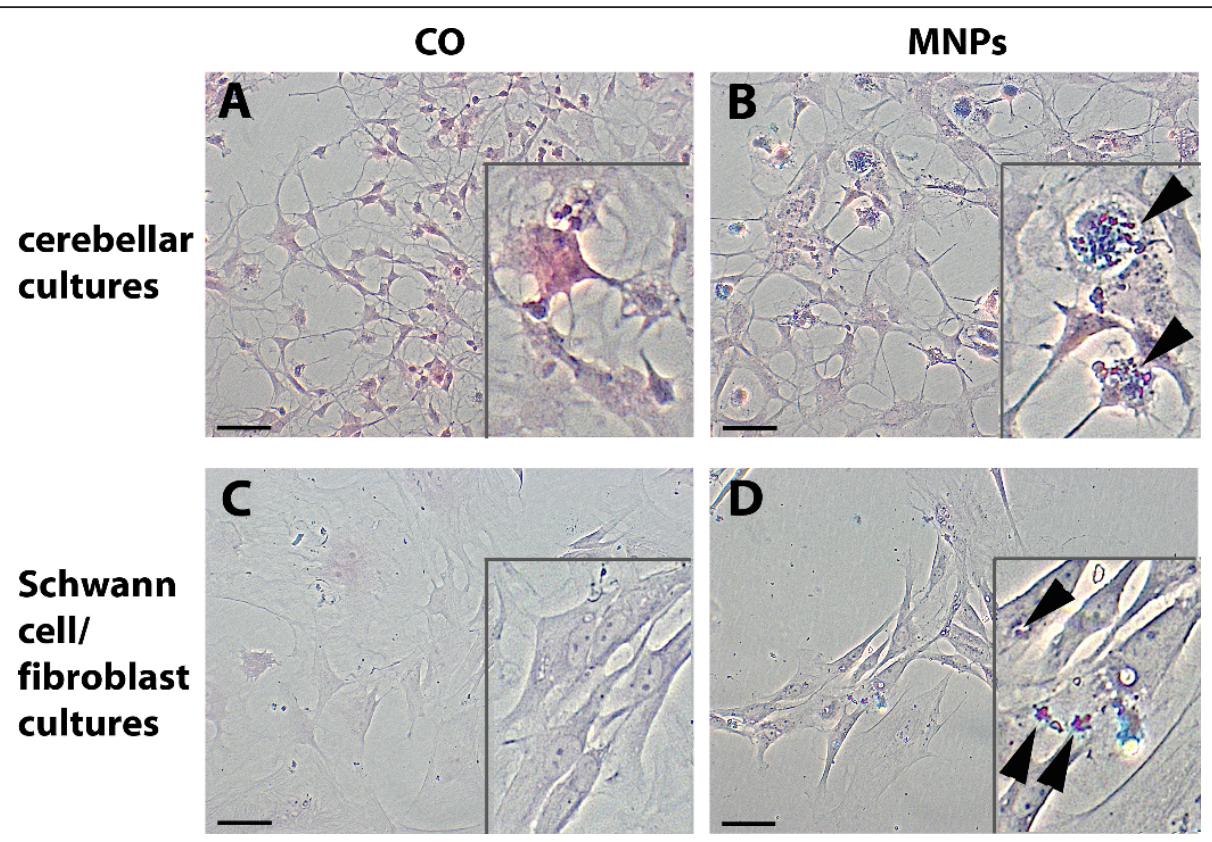

Figure 2 Cellular visualization of MNPs. Primary cerebellar and Schwann cell/fibroblast cultures are stained with nuclear fast red-aluminium sulphate (visualizing the cells) and Prussian blue (visualizing MNPs). (A) shows control (CO) cerebellar cells and (B) cerebellar cells incubated with MNPs. (C) illustrates Schwann cell/fibroblast cultures of the control and (D) incubated with MNPs. Arrows indicate stained MNPs. Bars represent $50 \mu \mathrm{m}$. 


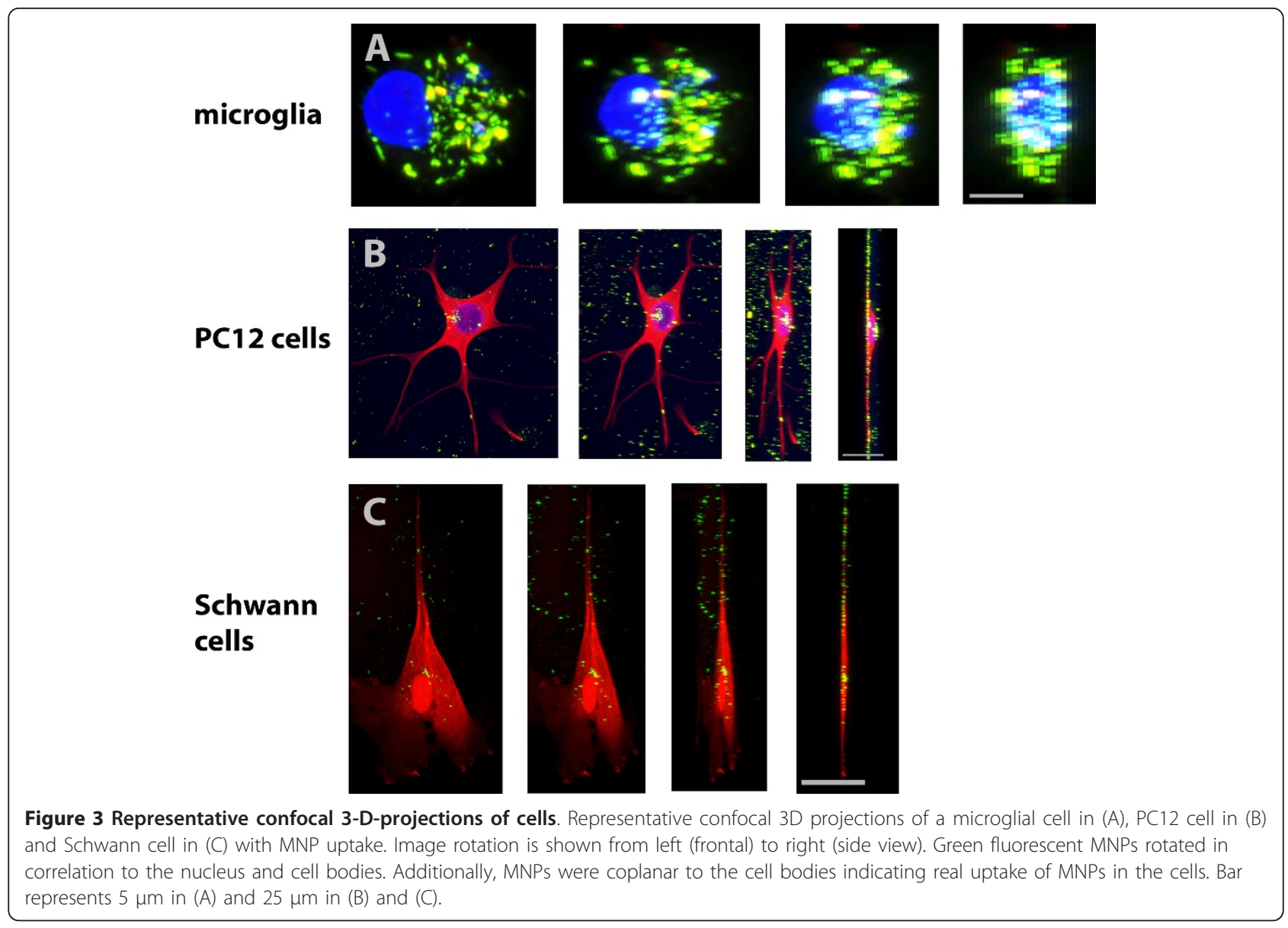

and PC12 cells with MNPs for 24 h did not effect the cell number of both cell types (primary neurons $\mathrm{p}=$ $0.69, \mathrm{n}=20$, Figure $5 \mathrm{~A}$; unpaired t-test, $\mathrm{PC} 12$ cells $\mathrm{p}=$ $0.47, \mathrm{n}=20$, Figure $5 \mathrm{~B}$ ).
The comparison of the uptake potential of neuronal differentiated PC12 cells with primary neuronal cells demonstrated that $76.9 \%( \pm 11.8 \% \mathrm{SD})$ of MNPs had been uptaken in PC12 cells compared with only $12.8 \%$

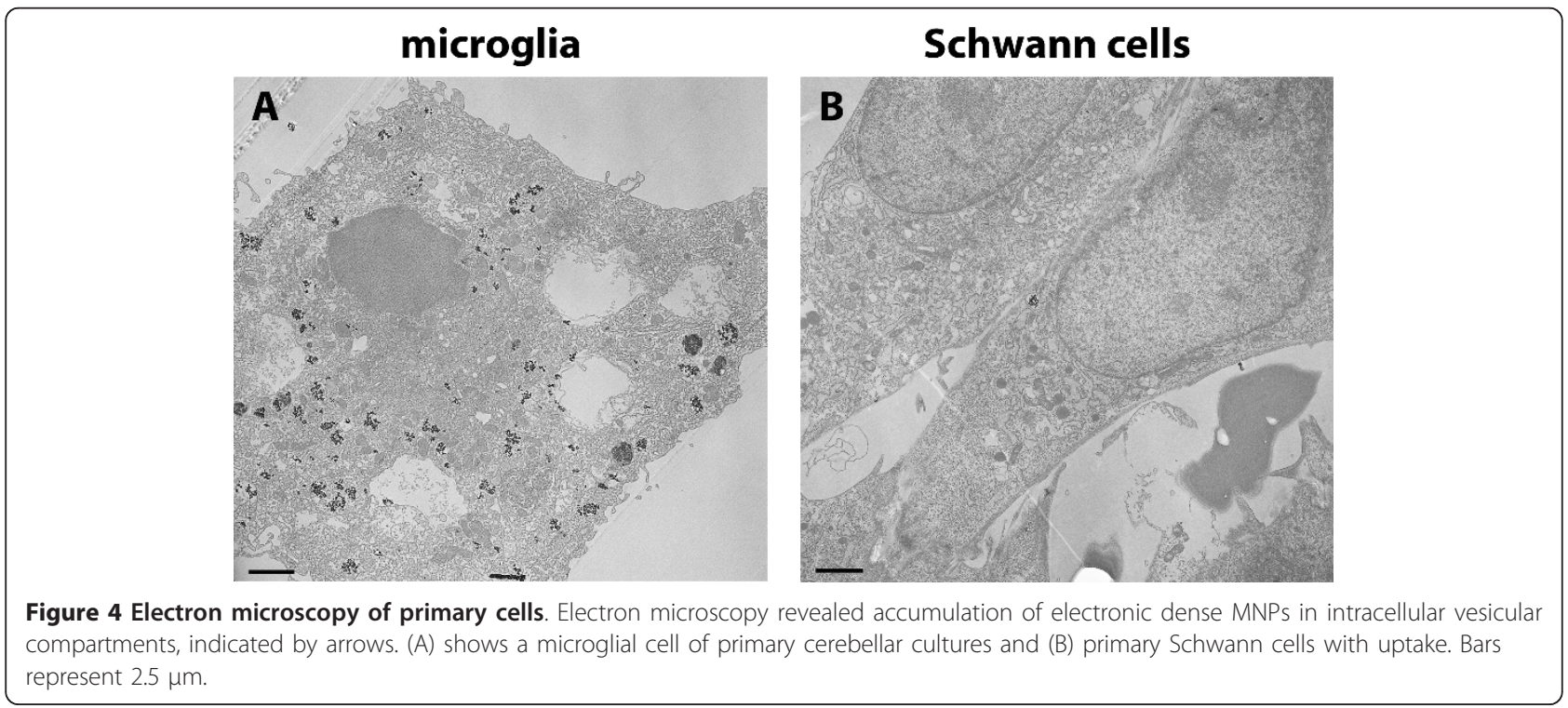




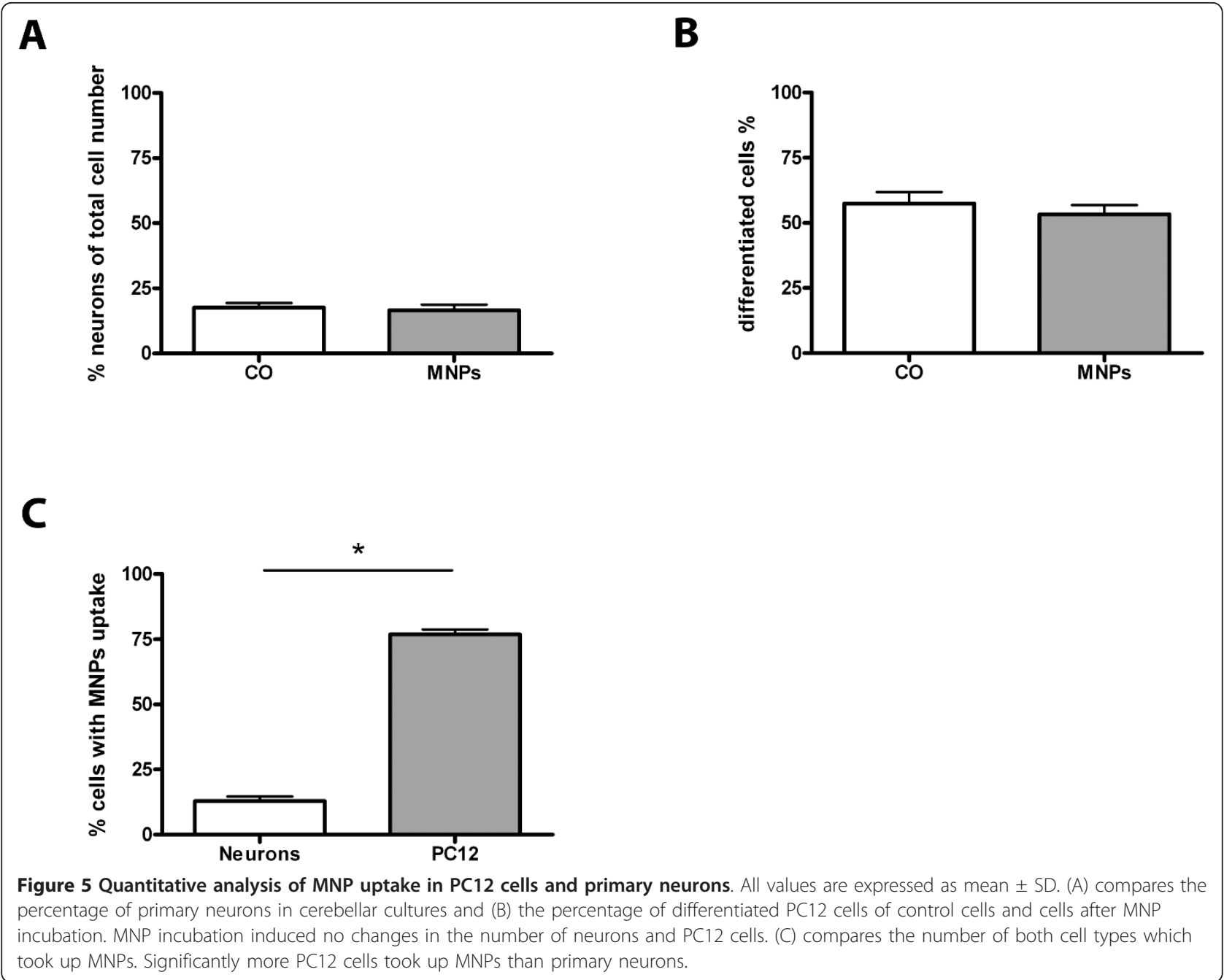

$( \pm 13.2 \% \mathrm{SD})$ in the primary neurons (Figure $5 \mathrm{C}$ ). Representative fluorescent images of PC12 cells and neurons with MNP uptake are shown in Figure 6. Control cells (PC12 cells in Figure 6A, primary neurons in Figure 6C) illustrated no green fluorescence whereas cells incubated with MNPs showed green fluorescent MNPs co-localized with PC12 cells (Figure 6B) and primary neurons (Figure 6D).

Besides neurons, cerebellar cultures contain different types of glial cells. For analysis of glia cells, we stained the cultures for glia cell type specific antibodies on DIV 7. At this time, cultures contained $35.4 \%( \pm 2.8 \% \mathrm{SD})$ microglia in control cultures and $43.2 \%( \pm 2.5 \% \mathrm{SD})$ microglia in cultures incubated with MNPs. MNP incubation for $24 \mathrm{~h}$ increased the number of microglia by $7.8 \%( \pm 3.8 \% \mathrm{SD})$ (unpaired t-test, $\mathrm{p}=0.046, \mathrm{n}=20$, Figure 7A). Astroglia in control cultures represented $67.8 \%( \pm 3.0 \% \mathrm{SD})$ and in cultures incubated with MNPs $67.7 \%( \pm 1.8 \%$ SD). No changes in the amount of astroglia were induced by MNP incubation (unpaired t-test, $\mathrm{p}=0.98, \mathrm{n}=20$, Figure $7 \mathrm{~B}$ ).
For analysis of oligodendroglia, the cultures were stained on DIV 13 with an oligodendroglial marker. $6.9 \%( \pm 1.1 \%$ SD) oligodendroglia were found in control cultures and $5.9 \%( \pm 1.0 \% \mathrm{SD})$ in cultures incubated with MNPs. The percentage of oligodendroglia did not change by MNP incubation (unpaired t-test, $\mathrm{p}=0.52, \mathrm{n}=19$, Figure $7 \mathrm{C}$ ). The comparison between the different cerebellar cell types revealed significant differences in the number of cells which took up MNPs (Figure 7D): 78.7\% ( $\pm 12.2 \%$ SD) of microglia, $41.0 \%$ ( $\pm 14.9 \% \mathrm{SD}$ ) of astroglia, $19.2 \%$ ( $\pm 23.9 \%$ $\mathrm{SD})$ of oligodendroglia and $12.8 \%( \pm 11.8 \% \mathrm{SD})$ of neurons showed uptake of MNPs (one-way ANOVA, p < 0.001). Representative images of glial cell types with MNP uptake are shown in Figure 8. Microglia of control cultures are illustrated in Figure 8A, astroglia in Figure 8C and oligodendroglia in Figure 8E. All lacked green fluorescent signals. The green fluorescent MNPs are clearly seen in cultures incubated with MNPs for $24 \mathrm{~h}$ (see microglia in Figure 8B, astroglia in Figure 8D and oligodendroglia in Figure $8 \mathrm{~F}$, arrows). The images also show differences in 


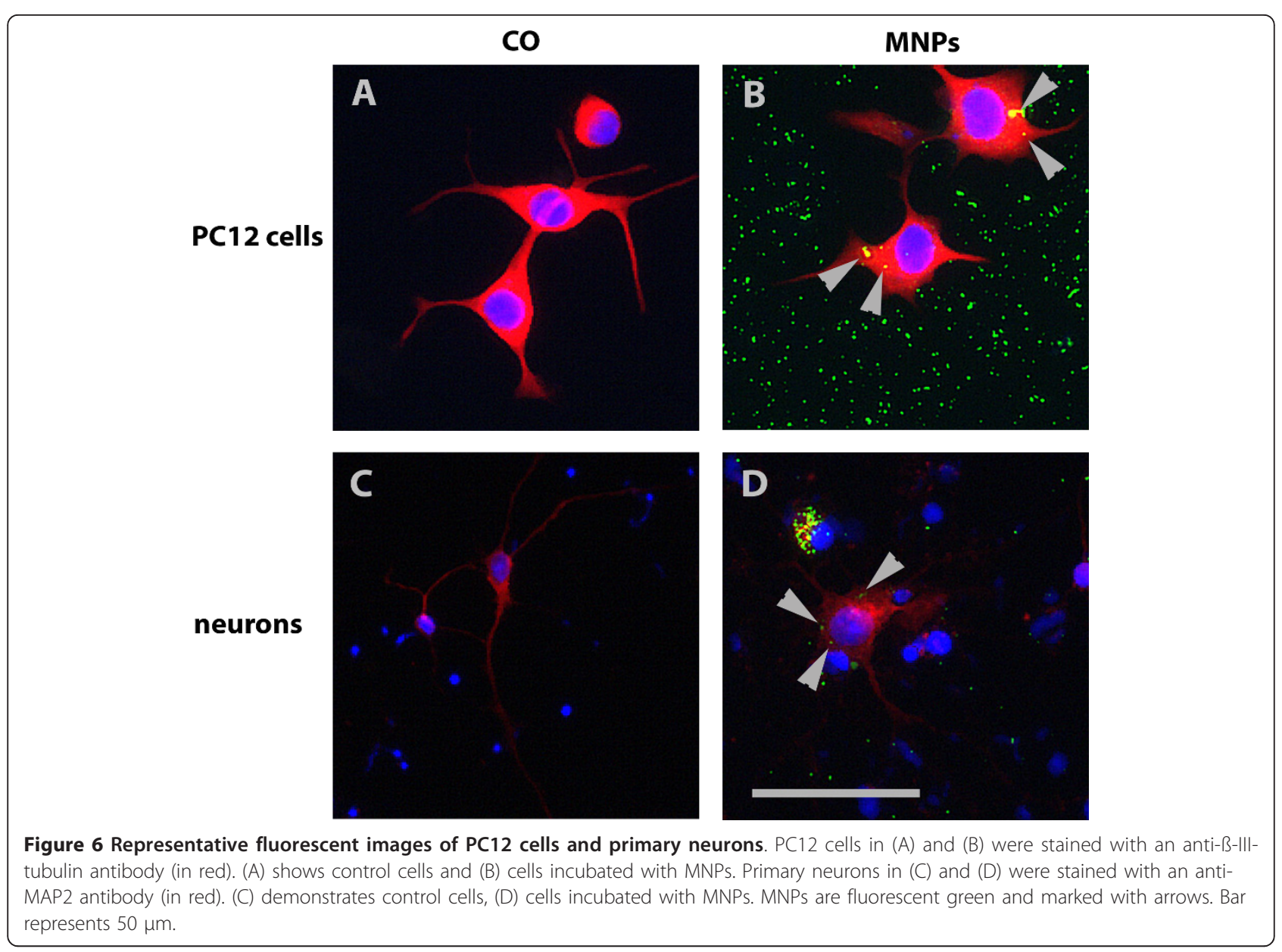

the cellular uptake of MNPs. Stained microglia clearly demonstrated a higher content of MNPs per cell than the other cell types (Figure 8B, arrow).

Although there is an increase in cell number of microglia in cultures incubated with MNPs, the viability assay revealed no significant differences between control cells and cells incubated with 10,50 and $100 \mu \mathrm{g} / \mathrm{ml}$ MNPs (data not shown) (one-way ANOVA, $\mathrm{p}>0.05, \mathrm{n}=12$ ).

Mixed Schwann cell/fibroblast cultures were used on DIV 7 and contained $61.9 \%( \pm 3.3 \%$ SD) Schwann cells in control cultures. The incubation with MNPs induced a decrease of $17.1 \%( \pm 5.5 \% \mathrm{SD})$ in the number of Schwann cells to $44.8 \%( \pm 5.5 \%$ SD) Schwann cells (unpaired t-test, $\mathrm{p}=0.012, \mathrm{n}=20$, Figure 9A). 61.4\% $( \pm$ $4.4 \% \mathrm{SD}$ ) of fibroblast were found in the control cultures and $73.5 \%( \pm 4.3 \% \mathrm{SD})$ in cultures incubated with MNPs indicating a trend of an increased number of fibroblasts (unpaired t-test, $\mathrm{p}=0.054, \mathrm{n}=20$ ) compared to controls (Figure 9B). Nevertheless, Schwann cells seem to be more sensitive to the MNPs then fibroblasts, but their uptake capacity is similar: $61.1 \%( \pm 3.2 \% \mathrm{SD})$ of Schwann cells and $58.1 \%( \pm 3.9 \% \mathrm{SD})$ of fibroblasts showed uptake of MNPs after 24 h incubation time (unpaired t-test, $\mathrm{p}=0.544, \mathrm{n}=40$, Figure 9C). Representative images of Schwann cells and fibroblasts with MNP uptake are illustrated in Figure 10. Schwann cells and fibroblasts of the control cultures lacked green fluorescent signals (Figure 10A, C), but cells incubated with MNPs showed green fluorescent MNPs co-localized with the cells (see Schwann cells in Figure 10B and fibroblasts in Figure 10D, arrows).

The viability assay revealed no significant differences in viability between control cells and cells incubated with 10,50 or $100 \mu \mathrm{g} / \mathrm{ml}$ MNPs for $24 \mathrm{~h}$ (data not shown) (one-way ANOVA, p > 0.05, $\mathrm{n}=10$ ).

\section{Organotypic co-cultures}

Organotypic co-cultures of spinal cord and peripheral nerves were used to verify the results of the dispersed cultures of the CNS and PNS in a more complex model. MNPs were not found inside of motor neurons and their neurites (Figure 11A, B) or in Schwann cells guiding sprouting neurites. Microglia revealed vesicular accumulation of huge amounts of MNPs inside the cells 


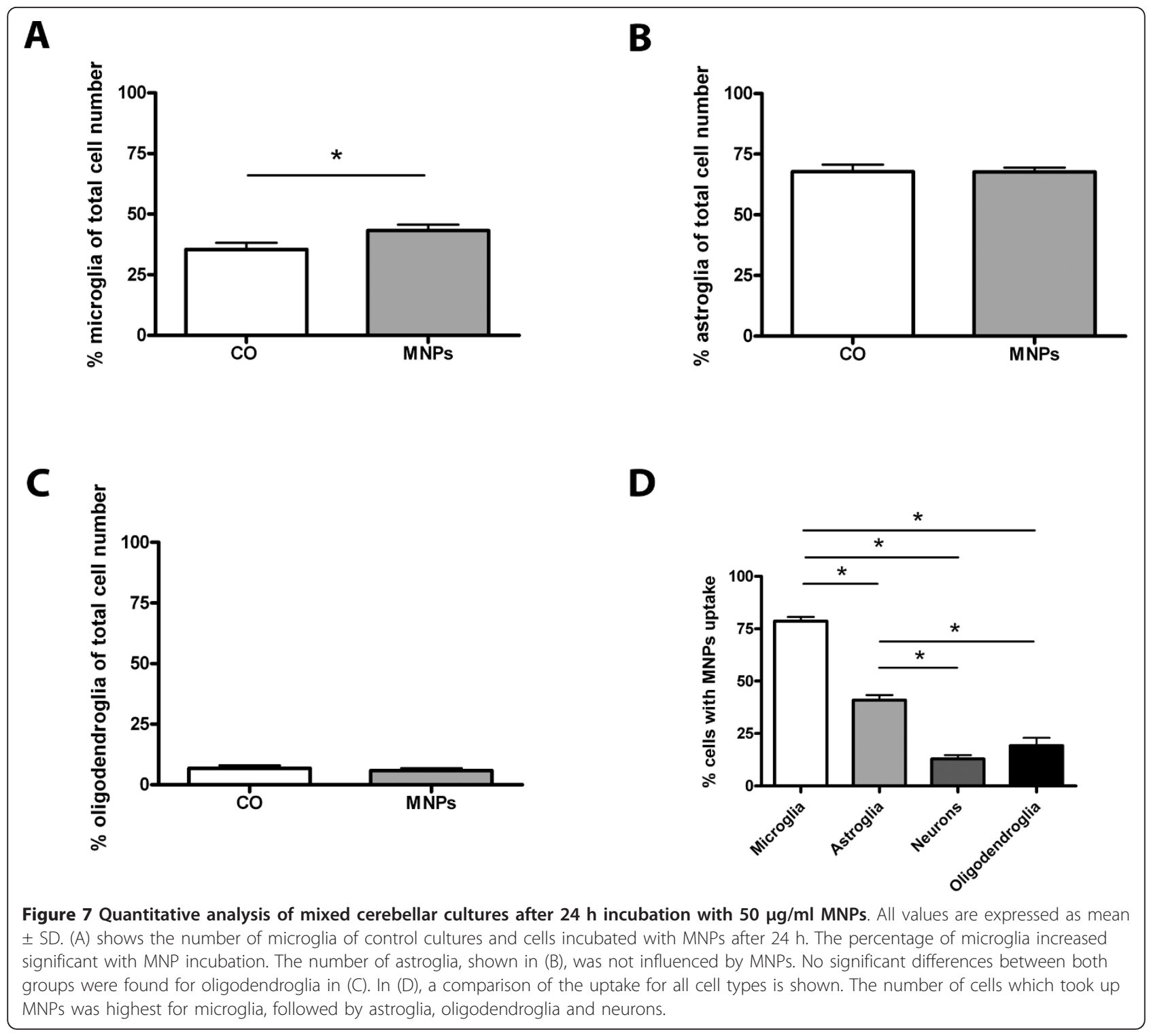

(Figure 11C, D). Astroglia (Figure 11E, F) and oligodendroglia took up MNPs and showed single accumulation. Thus, uptake in organotypic culture resembles the uptake observed in dispersed cultures.

\section{Discussion}

Literature regarding primary cell cultures, especially of the nervous system and nanoparticles, is limited. Most previous studies in nanosciences use cell lines such as PC12 as a neuronal model $[16,18]$. However, cell lines are often tumour cells or immortalised cells behaving differently than primary cells $[21,22]$. PC12 cells show a reliable uptake of nanoparticles: Non-functionalized polymer-coated nanoparticles were found to be internalized in the cytoplasm in a highly non-specific manner [31], without toxic effects. Pisanic II et al. [18] demonstrated a qualitative proportional uptake of anionic nanoparticles, indicating non-limited uptake for the used concentrations. Even biological functions of PC12 cells could be influenced by nanoparticles. Hussain et al. [32] for example, depleted dopamine and dopamine metabolites with manganese oxide particles in a dosedependent manner. Comparing differentiated PC12 cells and primary cerebellar neurons in our study, we found significant differences in the uptake of MNPs. A high cellular uptake was observed in the PC12 cells compared with only about $13 \%$ in primary neurons. Obviously, PC12 cells are a questionable choice for exploring the response of neurons to nanoparticles and do not predict neuronal uptake of primary neurons.

We used mixed cerebellar cultures to model interactions of the major cell types of the CNS. They contain, 


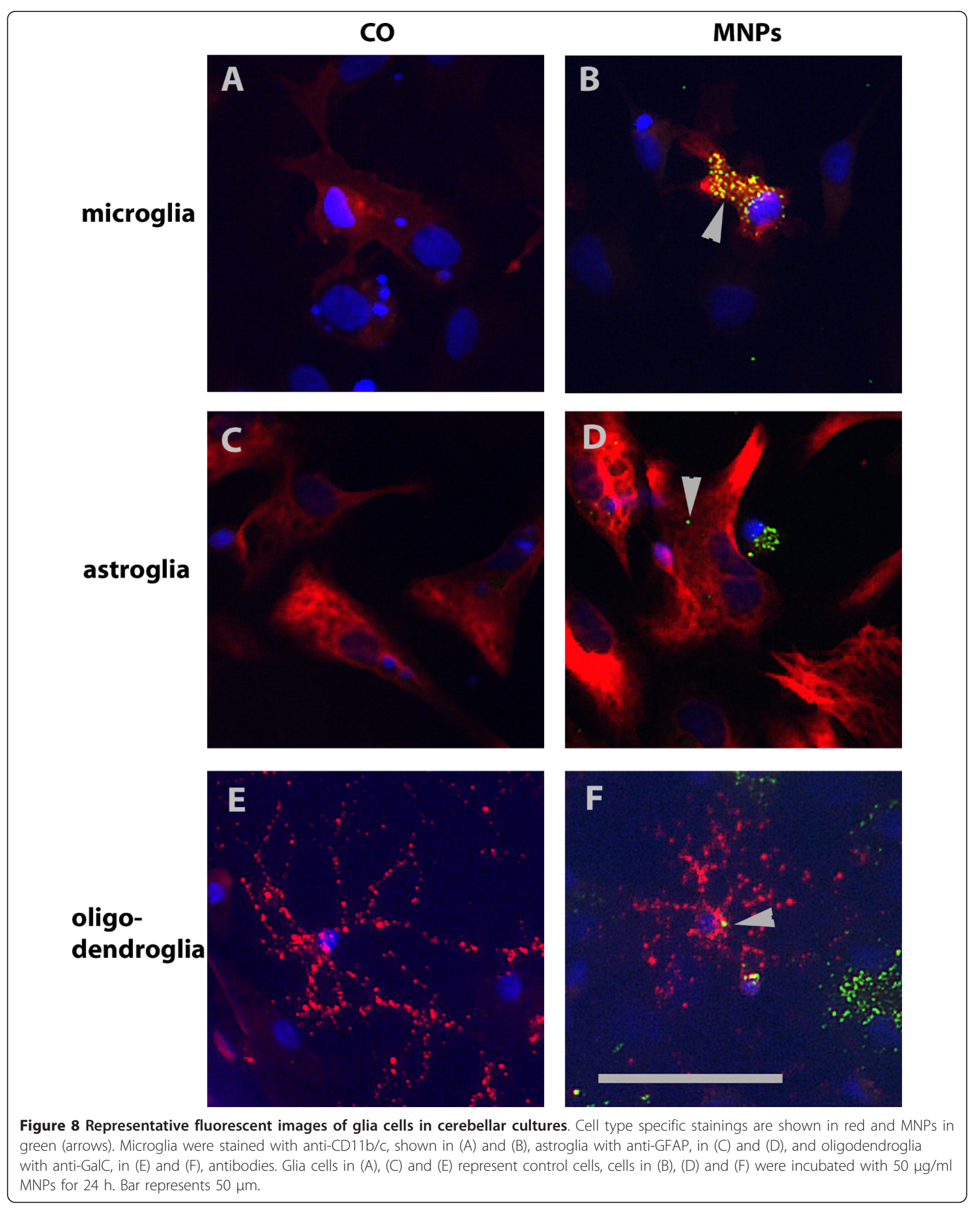




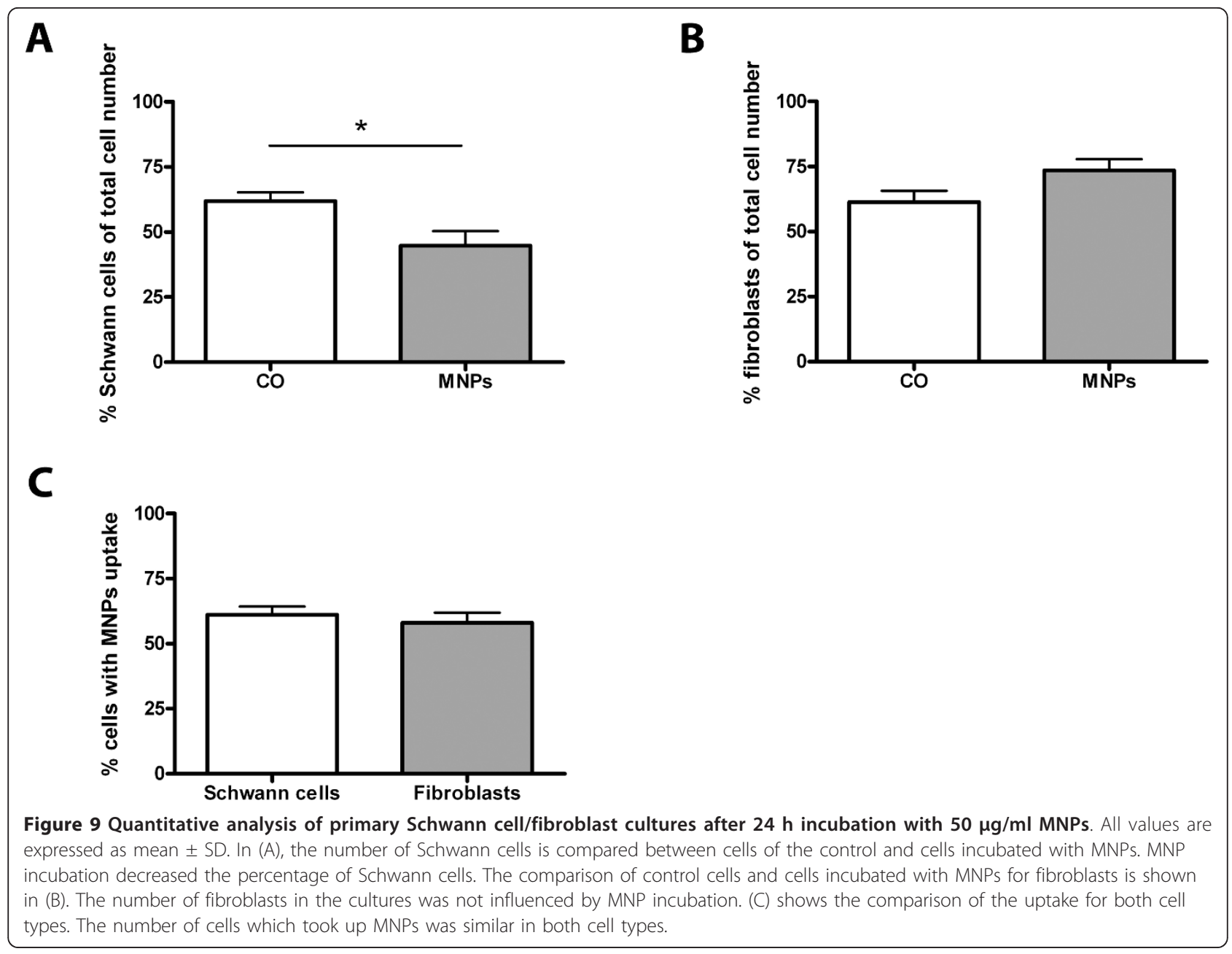

apart from neurons, microglia, astroglia and oligodendroglia, which all have the potential to internalize MNPs [33-35]. However, the uptake of MNPs was distinct between the different cell types of these primary cultures. MNPs were found to be predominantly taken up by microglia.

Microglial cells are resident macrophages of the CNS, sensing cell damage and pathogens [36]. If microglia are activated by a stimulus, they change their morphology, up-regulate immunologically relevant molecules such as chemokine receptors, major histocompatibility complex molecules and phagocytic receptors [37,38], and phagocytose possible pathogens. Lundqvist et al. [39] showed that nanoparticles become surrounded by a protein corona if they are suspended in blood plasma. Different particle sizes and charges resulted in different coronas which were composed for example of immunglobulins, lipoproteins and complement factors. This protein corona results in an opsonization of nanoparticles and phagocytosis by macrophages and microglia [40,41]. Given that the MNPs used in this study were suspended in serum containing medium, it is possible to assume an opsonization of the MNPs by serum proteins which stimulate the microglia to phagocytose. We found that nearly $80 \%$ of the microglia in these cultures took up MNPs. Additionally, microglia proliferate in response to pathogens $[42,43]$. This was demonstrated in our study, too. The number of microglia increased after incubation with MNPs. This indicates activation of the microglia through the MNPs and suggests a problem for in vivo application. Microglia would phagocytose the administered MNPs before they could target other cells such as neurons. Additionally, they would trigger immune responses and influence other cell types. This could counteract with the goal to use the MNPs for the promotion of nerve regeneration in pathological conditions.

MNPs were also internalized by astroglia and oligodendroglia, but to a lesser extent. Phagocytosis is described in the literature for both glia types, too. However, the potential seems to be lower than for microglia and differs in velocity between the cell types [44-47], which could explain the different uptake of the glial cell types found 


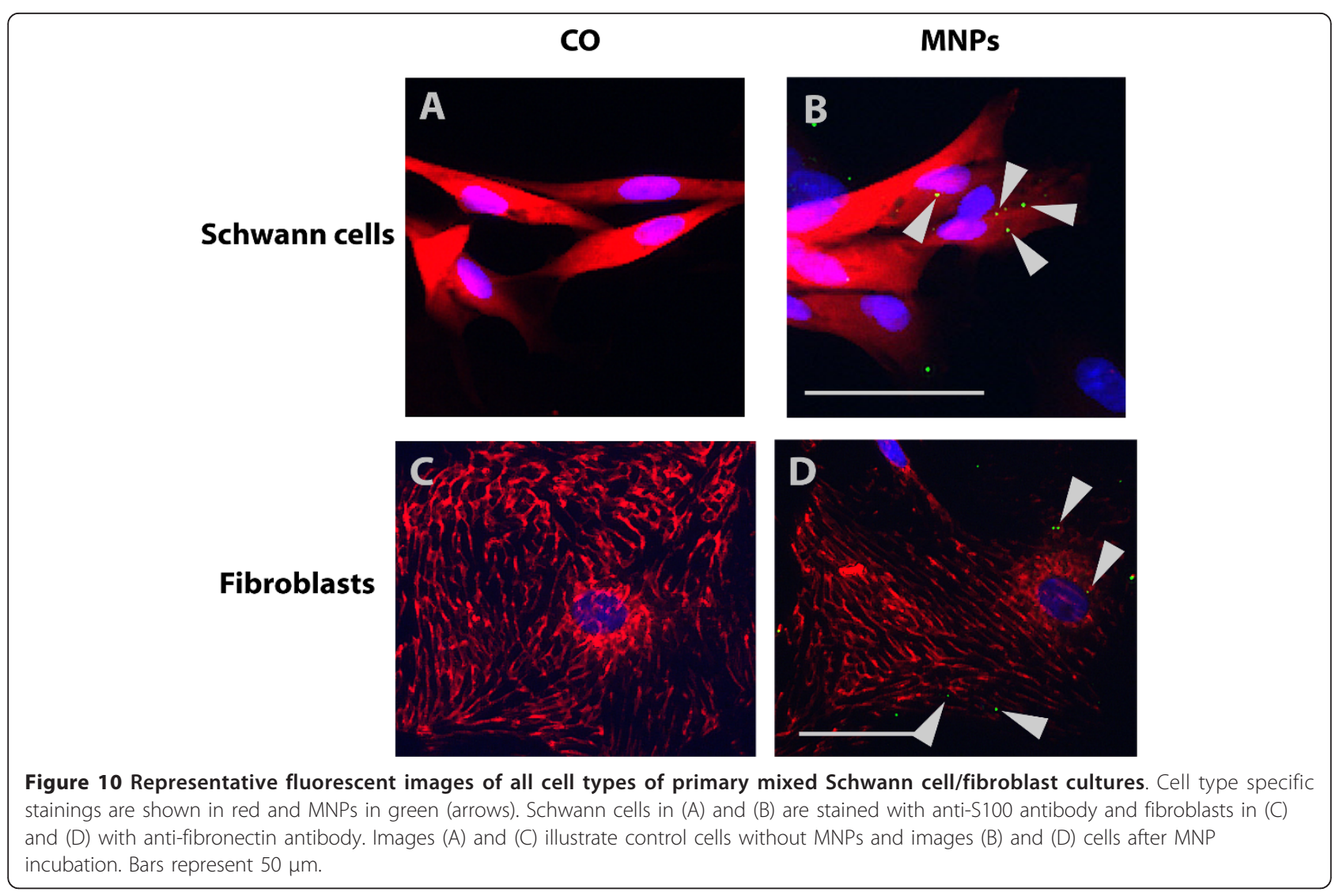

in our study. In purified cultures, astroglia as well as oligodendroglial precursor cells revealed a satisfying uptake of different kinds of nanoparticles [33-35]. Purified cultures just give information about single cell types and lack the interactions between the various cell populations that can be found in tissues. Also Pickard and Chari [33], who showed robust nanoparticle uptake in purified primary microglia, pointed out the importance of studies comparing and analyzing nanoparticle uptake in the major cell populations of the CNS. Our study, using mixed cultures of the CNS and PNS, bridges this gap and take the interactions of the cell types into account. Additionally, Pickard and Chari [33] predicted in their study "... that the rapid and extensive MNP uptake by endogenous microglia could represent a significant 'extracellular' barrier to particle uptake by other neural cell subpopulations." The results of our study confirm their prediction. As mentioned above, most MNPs were phagocytosed by the microglial cells in the mixed cultures which presumably reduce the amount of MNPs for uptake by other cells.

The mixed Schwann cell/fibroblast cultures model the PNS environment. The PNS environment and especially the Schwann cells influence nerve regeneration in the nervous system, too. Both cell types took up MNPs and do not show phagocytosis under normal conditions. But both cell types are able to activate phagocytic potential with appropriate stimulation. Schwann cells are able to activate phagocytic functions during injury of the nerve and clear the injury site of cell and myelin debris $[14,48]$. Also, in vitro, Schwann cells retain this function and can be stimulated to phagocytose applied myelin membranes within $1 \mathrm{~h}$ [49]. Fibroblasts, on the other hand, reveal substantial phagocytosis in wounds as well as under in vitro conditions [50-52]. In purified cultures, both cell types revealed reliable uptake of different kinds of nanoparticles [53,54].

Besides phagocytosis, different types of endocytotic pathways or diffusion [48] of the negatively charged MNPs, facilitated by positively charged membrane domains [55], could also be possible mechanisms for the cellular uptake of MNPs in astroglia, oligodendroglia, Schwann cells and fibroblasts and might explain the particular MNP uptake of the different cell types in our experiments.

Dispersed cultures do not model the in vivo situation and environment in total. Cells grow in a monolayer and lack certain cell-cell connections. Organotypic cultures offer a more complex and tissue-like environment for the cells. Due of this factor, they model the in vivo environment 


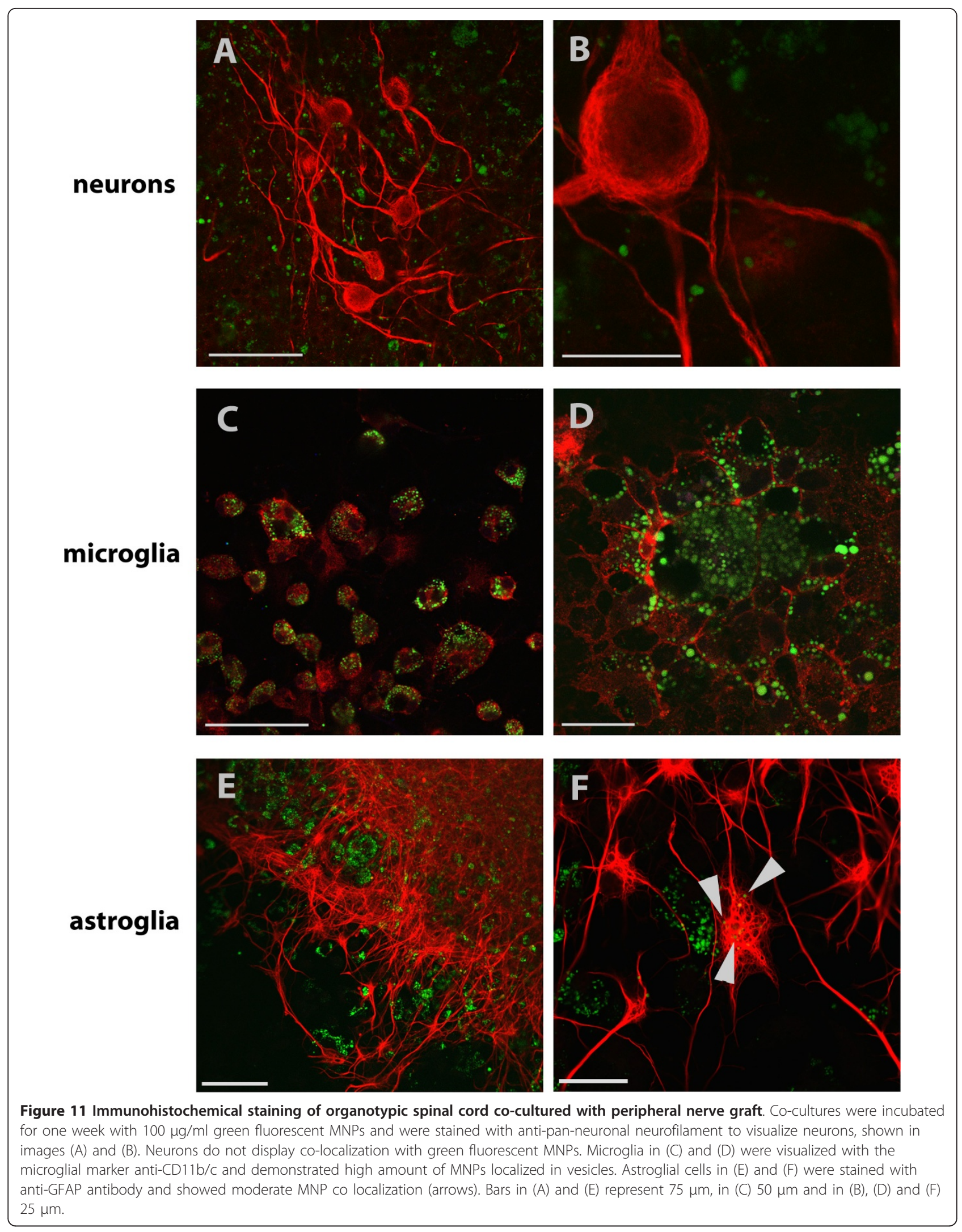


more adequately than dispersed cultures do. We compared our results of the dispersed primary cell cultures of the CNS and PNS to the organotypic co-culture of spinal cord slices (CNS) and peripheral nerve graft (PNS). The uptake of MNPs was similar between both systems. MNPs were internalized predominately in microglia of the spinal cord slice, but not in neurons. Astroglia, oligodendroglia and Schwann cells revealed uptake too, but again to a lesser extent.

Cellular uptake of exogenous particles might induce toxic effects. Toxicity of nanoparticles is a serious problem for biological and medical purposes. However, nanoparticles are not basically toxic. In human dermal fibroblasts, Gupta and Gupta [56] compared non-coated superparamagnetic iron oxide nanoparticles with polymer-coated particles and revealed a toxic effect of the non-coated particles and no toxic effect of the coated ones. On the other hand, Karlsson et al. [57] compared different metal oxide nanoparticles of different sizes concerning their influences on viability and mitochondrial and DNA damage. They found size- and metal oxide-dependent toxic effects and reported low toxicity of iron oxide particles. The MNPs used in this study showed only low toxicity towards Schwann cells. This would make them useful candidates for in vivo applications in the nervous system concerning toxicity at first view.

Given that dissociated and organotypic cultures show similar uptake results, it is likely that these commercial MNPs, although they show low toxicity, will not be easy to use in vivo in the nervous system. They activate the immune cells of the CNS and are phagocytosed by microglia in high numbers. Thus, for targeting cells other than microglia, the MNPs have to be tagged with a celltype specific marker. Additional functionalizing of MNPs with receptor agonists for a receptor-mediated uptake mechanism [58] or a more lipophilic coating to increase membrane permeability can improve cell-specific uptake [59]. Once the MNPs are taken up in a sufficient amount and frequency by specific cells of the nervous system, they can be used for locally influencing cell responses to axonal injury, for example with the delivery of siRNA or transplantation of supporting cells. Also, delivery of local drugs, growth factors, hormones and extracellular matrix molecules in and on the cell surface to influence cell responses $[49,60]$ is possible through manipulation of MNP localization with an external magnetic field.

\section{Conclusion}

Nanoparticles offer a large range of applications in life and neurosciences. Their functionality often depends on the fact that they are internalized by cells. Thus, we analyzed the uptake of commercially available MNPs in cells of the nervous system and were able to show that PC12 cells differ in their uptake to primary neuronal cells, and thus are not an appropriate choice for answering questions concerning the response of neurons to nanoparticles. MNPs in primary cerebellar and in organotypic co-cultures were found to be predominantly taken up by microglia, suggesting a problem for in vivo application of these commercial MNPs because of the immune response. Future research needs to overcome this immune system activation with cell-specific targeting and additional functionalization.

\section{Abbreviations}

ANOVA: Analysis of variance; BSA: Bovine serum albumin; CNS: Central nervous system; DAPI: 4',6-diamidino-2-phenylindole; DIV: Day in vitro; DMEM: Dulbecco's modified eagle medium; FCS: Fetal calf serum; GDNF: glial cell line-derived neurotrophic factor; GFAP: Glial fibrillary acidic protein; HBSS: Hank's balanced salt solution; HEPES: 4-(2-hydroxyethyl)-1piperazineethanesulfonic acid; hTERT-BJ1: Infinity ${ }^{\text {TM }}$ telomerase-immortalised primary human fibroblasts; HUVECs: Human umbilical vein endothelial cells; IBA-1: Ionized calcium binding adaptor molecule 1; MAP2: Microtubule associated protein-2; MEM: Eagle's minimal essential medium; MNPs: Magnetic nanoparticles; MTS: 3-(4,5-dimethylthiazol-2-yl)-5-(3-

carboxymethoxyphenyl)-2-(4-sulfophenyl)-2H-tetrazolium; NGF: Nerve growth factor; PBS: Phosphate buffered saline; PC12 cells: Rat pheochromocytoma cell line; PFA: Paraformaldehyde; PNS: Peripheral nervous system; Pen/strep: Penicillin/streptomycin; RPMI: Roswell park memorial institute.

\section{Acknowledgements}

This work was supported by grants from NanoscieE +2008 for the MARVENE project (magnetic nanoparticles for nerve regeneration). We grateful thank Leona Bück for her excellent technical help and Dr Clare Hoskins (School of Pharmacy, Institute for Science and Technology in Medicine, Keele University, Keele, UK) for revising the English.

\section{Author details}

${ }^{1}$ Institute of Biochemistry and Cell Biology, Otto-von-Guericke University Magdeburg, Leipziger Str. 44, 39120 Magdeburg, Germany. ${ }^{2}$ Instituto de Nanociencia de Aragón (INA), University of Zaragoza, Mariano Esquillor s/n, 50018 Zaragoza, Spain. ${ }^{3}$ Departamento de Física de la Materia Condensada, Facultad de Ciencias, Universidad de Zaragoza, 50009 Zaragoza, Spain.

${ }^{4}$ Department of Plastic, Reconstructive and Aesthetic Surgery, Hand Surgery, Klinikum Bielefeld, Teutoburger Str. 50, 33604 Bielefeld, Germany.

\section{Authors' contributions}

JP performed all cellular work, statistical analysis and microscopic work. She largely wrote the manuscript. PC and GFG performed all physical measurements of the magnetic nanoparticles and their analysis. They contributed to the writing of the manuscript. HF contributed the writing of the manuscript, too. GK conceived the experiments and contributed largely to the final version of the manuscript. All authors read and approved the final manuscript.

\section{Competing interests}

The authors declare that they have no competing interests.

Received: 9 January 2012 Accepted: 22 March 2012

Published: 22 March 2012

\section{References}

1. Li W, Chen C, Ye C, Wei T, Zhao Y, Lao F, Chen Z, Meng H, Gao Y, Yuan H, Xing G, Zhao F, Chai Z, Zhang X, Yang F, Han D, Tang X, Zhang Y: The translocation of fullerenic nanoparticles into lysosome via the pathway of clathrin-mediated endocytosis. Nanotechnol 2008, 19:145102. 
2. Shi H, He X, Yuan Y, Wang K, Liu D: Nanoparticle-based biocompatible and long-life marker for lysosome labelling and tracking. Anal Chem 2010, 82:2213-2220.

3. Pankhurst QA, Connolly J, Jones SK, Dobson J: Applications of magnetic nanoparticles in biomedicine. J Phys D-App/ Phys 2003, 36:R167-R181.

4. Gupta AK, Gupta M: Synthesis and surface engineering of iron oxide nanoparticles for biomedical applications. Biomaterials 2005, 26:3995-4021.

5. Suh WH, Suslick KS, Stucky GD, Suh Y-H: Nanotechnology, nanotoxicology, and neuroscience. Prog Neurobiol 2009, 87:133-170.

6. Sudimack J, Lee RJ: Targeted drug delivery via the folate receptor. Adv Drug Deliv Rev 2000, 41:147-162.

7. Darius J, Meyer FP, Sabel BA, Schroeder U: Influence of nanoparticles on the brain-to-serum distribution and the metabolism of valproic acid in mice. J Pharm Pharmacol 2000, 52:1043-1047.

8. Chertok B, Moffat BA, David AE, Yu F, Bergemann C, Ross BD, Yang VC: Iron oxide nanoparticles as a drug delivery vehicle for MRI monitored magnetic targeting of brain. Biomaterials 2008, 29:487-496.

9. Thiesen $B$, Jordan A: Clinical applications of magnetic nanoparticles for hyperthermia. Int J Hyperthermia 2008, 24:467-474.

10. Scherer $F$, Anton $M$, Schillinger $U$, Henke J, Bergemann C, Krüger $A$, Gänsbacher B, Plank C: Magnetofection: enhancing and targeting gene delivery by magnetic force in vitro and in vivo. Gene Ther 2002, 9:102-109.

11. Cooper DR, Nadau JL: Nanotechnology for in vitro neuroscience. Nanoscale 2009, 1:183-200.

12. McDonald JW, Sadowsky C: Spinal-cord injury. Lancet 2002, 359:417-425.

13. Yegiyants S, Dayicioglu D, Kardashian G, Panthaki ZJ: Traumatic peripheral nerve injury: a wartime review. J Craniofac Surg 2010, 21:998-1001.

14. Stoll G, Griffin JW, Li CY, Trapp BD: Wallerian degeneration in the peripheral nervous system: participation of both Schwann cells and macrophages in myelin degradation. J Neurocytol 1989, 18:671-683.

15. Vargas ME, Barres BA: Why is Wallerian degeneration in the CNS so slow? Annu Rev Neurosci 2007, 30:153-179.

16. Mittnacht U, Hartmann $H$, Hein S, Oliveira H, Dong M, Pêgo AP, Kjems J, Howard KA, Schlosshauer B: Chitosan/siRNA nanoparticles biofunctionalize nerve implants and enable neurite outgrowth. Nano Lett 2010, 10:3933-3939.

17. Hamasaki T, Tanaka N, Kamei N, Ishida O, Yanada S, Nakanishi K, Nishida K, Oishi Y, Kawamata S, Sakai N, Ochi M: Magnetically labelled neural progenitor cells, which are localized by magnetic force, promote axon growth in organotypic cocultures. Spine 2007, 32:2300-2305.

18. Pisanic TR, Blackwell JD, Shubayev VI, Finones RR, Jin S: Nanotoxicity of iron oxide nanoparticle internalization in growing neurons. Biomaterials 2007, 28:2572-2581.

19. Häfeli UO, Riffle IS, Harris-Shekhawat L, Carmichael-Baranauskas A, Mark F, Dailey JP, Bardenstein D: Cell uptake and in vitro toxicity of magnetic nanoparticles suitable for drug delivery. Mol Pharm 2009, 6:1417-1428.

20. Gupta AK, Curtis ASG: Surface modified superparamagnetic nanoparticles for drug delivery: Interaction studies with human fibroblasts in culture. $J$ Mater Sci Mater Med 2004, 15:493-496.

21. Wilkening S, Stahl F, Bader A: Comparison of primary human hepatocytes and hepatoma cell line HEPG2 with regard to their biotransformation properties. Drug Metab Dispos 2003, 31:1035-1042.

22. Pan C, Kumar C, Bohl S, Klingmueller U, Mann M: Comparative proteomic phenotyping of cell lines and primary cells to assess preservation of cell type-specific functions. Mol Cell Proteomics 2009, 8:443-450.

23. Thangnipon W, Kingsbury A, Webb M, Balazs R: Observations on rat cerebellar cells in vitro: influence of substratum, potassium concentration and relationship between neurones and astrocytes. Dev Brain Res 1983, 11:177-189.

24. Polazzi E, Gianni T, Contestabile A: Microglial cells protect cerebellar granule neurons from apoptosis: evidence for reciprocal signaling. Glia 2001, 36:271-280.

25. Levi G, Aloisi F, Wilkin GP: Differentiation of cerebellar bipotential glial precursors into oligodendrocytes in primary culture: developmental profile of surface antigens and mitotic activity. J Neurosci Res 1987, 18:407-417.

26. Aloisi F, Agresti C, D'Urso D, Levi G: Differentiation of bipotential glial precursors into oligodendrocytes is promoted by interaction with type-1 astrocytes in cerebellar cultures. Proc Natl Acad Sci 1988, 85:6167-6171.
27. Bernstein H-G, Keilhoff G, Bukowska A, Ziegeler A, Funke S, Dobrowolny $H_{\text {, }}$ Kanakis D, Bogerts B, Lendeckel U: ADAM (a disintegrin and metalloprotease) 12 is expressed in rat and human brain and localized to oligodendrocytes. J Neurosci Res 2004, 75:353-360.

28. Vyas A, Li Z, Aspalter M, Feiner J, Hoke A, Zhou C, O'Daly A, Abdullah M, Rohde C, Brushart TM: An in vitro model of adult mammalian nerve repair. Exp Neurol 2010, 223:112-118.

29. Kroll A, Pillukat MH, Hahn D, Schnekenburger J: Current in vitro methods in nanoparticle risk assessment: Limitations and challenges. Eur J Pharm Biopharm 2009, 72:370-377.

30. Mailänder V, Landfester K: Interaction of nanoparticles with cells. Biomacromolecules 2009, 10:2379-2400

31. Roy S, Johnston AH, Newman TA, Glueckert R, Dudas J, Bitsche M, Corbacell E, Rieger G, Martini A, Schrott-Fischer A: Cell-specific targeting in the mouse inner ear using nanoparticles conjugated with a neurotropinderived peptide ligand: Potential tool for drug delivery. Int J Pharm 2010, 390:214-224

32. Hussain SM, Javorina AK, Schrand AM, Duhart HM, Ali SF, Schlager JJ: The interaction of manganese nanoparticles with PC-12 cells induces dopamine depletion. Toxicol Sci 2006, 92:456-463.

33. Pickard MR, Chari DM: Robust uptake of Magnetic Nanoparticles (MNPs) by Central Nervous System (CNS) microglia: Implications for particle uptake in mixed neural cell populations. Int J Mol Sci 2010, 11:967-981.

34. Geppert M, Hohnholt MC, Thiel K, Nürnberger S, Grunwald I, Rezwan K, Dringen R: Uptake of dimercaptosuccinate-coated magnetic iron oxide nanoparticles by cultured brain astrocytes. Nanotechnology 2011, 22:145101-145111.

35. Jenkins SI, Pickard MR, Granger N, Chari DM: Magnetic nanoparticlemediated gene transfer to oligodendrocyte precursor cell transplant populations is enhanced by magnetofection strategies. ACS Nano 2011, 8:6527-6538.

36. Hanisch UK, Kettenmann H: Microglia: active sensor and versatile effector cells in the normal and pathologic brain. Nat Neurosci 2007, 10:1387-1394

37. Ponomarev ED, Shriver LP, Maresz K, Dittel BN: Microglial cell activation and proliferation precedes the onset of CNS autoimmunity. J Neurosci Res 2005, 81:374-389.

38. Baloui $H$, Stettler $O$, Weiss $S$, Nothias F, Boxberg Y: Upregulation in rat spinal cord microglia of the nonintegrin laminin receptor $37 \mathrm{kDa}-\mathrm{LRP}$ following activation by a traumatic lesion or peripheral injury. J Neurotrauma 2009, 26:195-207.

39. Lundqvist M, Stigler J, Elia G, Lynch I, Cedervall T, Dawson KA: Nanoparticle size and surface properties determine the protein corona with possible implications for biological impacts. PNAS 2008, 105:14265-14270.

40. Owens DE, Peppas NA: Opsonization, biodistribution, and pharmacokinetics of polymeric nanoparticles. Int J Pharm 2006, 307:93-102.

41. Nel AE, Mädler L, Velegol D, Xia T, Hoek EMV, Somasundaran P, Klaessig F, Castranova V, Thompson M: Understanding biophysicochemical interactions at the nano-bio interface. Nat Mater 2009, 8:543-557.

42. Suzumura A, Marunouchi T, Yamamoto H: Morphological transformation of microglia in vitro. Brain Res 1991, 545:301-306.

43. Aloisi F, de Simone R, Columba-Cabezas S, Levi G: Opposite effects of Interferon- $\gamma$ and Prostaglandin E2 on Tumor Necrosis Factor and Interleukin-10 production in microglia: A regulatory loop controlling microglia pro-and anti-inflammatory activities. J Neurosci Res 1999, 56:571-580.

44. Noske W, Lentzen H, Lange K, Keller K: Phagocytotic activity of glial cells in culture. Exp Cell Res 1982, 142:437-445.

45. Triarhou LC, Del Cerro M, Herndon RM: Ultrastructural evidence for phagocytosis by oligodendroglia. Neurosci Lett 1985, 53:185-189.

46. Saito $H$, Tomioka $H$, Sato $K$, Watanabe $T$ : Abilities of human oligodendroglial cells and mouse Schwann cells to phagocytose Mycobacterium leprae and other mycobacteria. Infect Immun 1986, 51:157-162.

47. Tansey FA, Cammer W: Differential uptake of dextran beads by astrocytes, macrophages and oligodendrocytes in mixed glial-cell cultures from brains of neonatal rats. Neurosci Lett 1998, 248:159-162.

48. Unfried K, Albrecht C, Klotz L-O, Mikecz A, Grether-Beck S, Schins RPF: Cellular responses to nanoparticles: Target structures and mechanisms. Nanotoxicology 2007, 1:52-71. 
49. Chen Z-L, Yu W-M, Strickland S: Peripheral regeneration. Annu Rev Neurosci 2007, 30:209-233.

50. Bigbee JW, Yoshino JE, DeVries GH: Morphological and proliferative responses of cultured Schwann cells following rapid phagocytosis of a myelin-enriched fraction. J Neurocytol 1987, 16:487-496.

51. Arlein WJ, Shearer JD, Caldwell MD: Continuity between wound macrophage and fibroblast phenotype: analysis of wound fibroblast phagocytosis. Am J Physiol Regul Integr Comp Physiol 1998, 275: R1041-R1048.

52. Abraham LC, Dice JF, Lee K, Kaplan DL: Phagocytosis and remodelling of collagen matrices. Exp Cell Res 2007, 313:1045-1055.

53. Berry CC, Wells S, Charles S, Curtis ASG: Dextran and albumin derivatised iron oxide nanoparticles: influence on fibroblasts in vitro. Biomaterials 2003, 24:4551-4557.

54. Dunning MD, Lakatos A, Loizou L, Kettunen M, ffrench-Constant C, Brindle KM, Franklin RJM: Superparamagnetic iron oxide-labeled Schwann cells and olfactory ensheating cells can be traced in vivo by magnetic resonance imaging and retain functional properties after transplantation into the CNS. J Neurosci 2004, 24:9799-9810.

55. Luciani N, Gazeau F, Wilhelm C: Reactivity of the monocyte/macrophage system to superparamagnetic anionic nanoparticles. J Mater Chem 2009, 19:6373-6380

56. Gupta AK, Gupta M: Cytotoxicity suppression and cellular uptake enhancement of surface modified magnetic nanoparticles. Biomaterials 2005, 26:1565-1573.

57. Karlsson HL, Gustafsson J, Cronholm P, Möller L: Size-dependent toxicity of metal oxide particles - A comparison between nano- and micrometer size. Toxicol Lett 2009, 188:112-118.

58. Patel PC, Giljohann DA, Daniel WL, Zheng D, Prigodich AE, Mirkin CA: Scavenger receptors mediate cellular uptake of polyvalent oligonucleotide-functionalized gold nanoparticles. Bioconjug Chem 2010, 21:2250-2256

59. Nativo P, Prior IA, Brust M: Uptake and intracellular fate of surfacemodified gold nanoparticles. ACS Nano 2008, 2:1639-1644.

60. Fansa $H$, Schneider W, Wolf $G$, Keilhoff G: Influence of insulin-like growth factor-I (IGF-I) on nerve autografts and tissue-engineered nerve grafts. Muscle Nerve 2002, 26:87-93.

doi:10.1186/1471-2202-13-32

Cite this article as: Pinkernelle et al:: Magnetic nanoparticles in primary neural cell cultures are mainly taken up by microglia. BMC Neuroscience 2012 13:32.

\section{Submit your next manuscript to BioMed Central and take full advantage of:}

- Convenient online submission

- Thorough peer review

- No space constraints or color figure charges

- Immediate publication on acceptance

- Inclusion in PubMed, CAS, Scopus and Google Scholar

- Research which is freely available for redistribution

Submit your manuscript at www.biomedcentral.com/submit
Biomed Central 